\title{
Improved Mathematical Problem Solving Ability and Self Efficacy of Class VIII Students of SMP Negeri 1 Percut Sei Tuan through Problem Based Learning Models
}

\author{
Indah Dirgantari Ritonga ${ }^{1}$, Humuntal Banjarnahor ${ }^{2}$, Ani Minami ${ }^{3}$ \\ ${ }^{1,2,3}$ Universitas Negeri Medan, Indonesia \\ indahdirgantari@gmail.com,humbanjarnahor@gmail.com,animinarni10@gmail.com
}

\begin{abstract}
This study aims to describe whether the increase in mathematical problem solving abilities and Self Efficacy of students who are taught using problem-based learning models is higher than students who are taught with ordinary learning, to describe whether there is an interaction between students' initial mathematical abilities and learning towards increased mathematical problem solving abilities. students, as well as to describe whether there is an interaction between students' initial mathematical abilities and learning towards increasing student Self-Efficacy. Based on the ANOVA $2 \times 2$ calculation, it is obtained Fcount $=88.82$ while the Ftable value $=2.36$ for $d k$ (1.62) and a significant level of 5\%. It turns out that the value of Fcount> Ftable, so that Ho is rejected and Ha is accepted. Then from table 4. The probability value (sig) is smaller than 0.05 so that $\mathrm{HO}$ is rejected. Thus it can be concluded that the results of students' mathematical problem-solving abilities taught by problem-based learning models are better than those taught with ordinary learning models. The results of students' Self Efficacy in the problem-based learning model class were higher than in the ordinary learning model class. This can also be seen from the average results of the mathematics Self Efficacy questionnaire of students with the experimental class (99.7) which are higher than the average results of the mathematics Self Efficacy questionnaire of students with the control class (96.8). The results of students' Self Efficacy in the problem-based learning model class were higher than in the ordinarylearning model class. This can also be seen from the average results of the mathematics Self Efficacy questionnaire of students with the experimental class (99.7) which are higher than the average results of the mathematics Self Efficacy questionnaire of students with the control class (96.8). $X^{-}=X^{-}=$
\end{abstract}

Keywords

mathematical problem solving ability; student self efficacy, problem based learning model

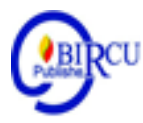

\section{Introduction}

Mathematics is a science that has the characteristics of deductive reasoning, namely the truth of a concept or statement is obtained as a logical result of the previous truth (Banjarnahor, 2018). Mathematics is one of the education sciences that is fundamentally developed in people's lives and is very much needed in the development of science and technology. According to Delina, et al. (2015), along with the presence of science and technology, the world of mathematics education cannot be separated from the perspective of the $21 \mathrm{st}$ global education. In other words, education demands human quality and 
innovative abilities. In everyday life, mathematics is often used in solving problems faced by humans.

Through good mathematics education, students can indeed obtain various kinds of provisions in facing challenges in the global era. In the 2013 curriculum itself, the use of technology in learning became something that was highly recommended. The learning process in the 2013 curriculum requires students to participate actively and provide sufficient space for students' creativity, interests, and talents (Fitri, Syahputra, \& Syahputra, 2019).

The importance of problem-solving skills by Kirkley (2003) states that problemsolving abilities include higher-order thinking skills such as visualization, association, abstract thinking, comprehensive, manipulation, analysis, synthesis, generalization, each of which requires rules and coordination.

The view that the ability to solve problems is a general goal of teaching mathematics implies that mathematics can help solve problems both in other subjects and in everyday life. Therefore this problem-solving ability is the general goal of learning mathematics.

In addition, problem solving is also a core and main process in the mathematics curriculum, meaning that problem solving learning prioritizes the processes and strategies that students do in solving them rather than just results. So that process skills and strategies in solving these problems become basic skills in learning mathematics.

Based on the results of a review of several literatures, the indicators for measuring mathematical problem solving abilities are: (1) Students can understand problems (Comprehension), (3) Students can transform problems (Transformation), (4) Students can solve problems and (5) Students can conclude the solution according to the initial problem.

The Indonesian government has made various efforts to improve the quality of teaching and improve student mathematics learning outcomes, because mathematics is a very important science in every level of education pursued by every Indonesian citizen. Government efforts include developing curricula, providing training to teachers, completing educational infrastructure and even improving teacher welfare. Along with the development of the internet, learning strategies have shifted and various information and communication technology based learning strategies emerge from the e-learning model. Smart classroom technology, virtual classroom, belded learning, etc. (Fitri \& Zahari, 2019).

\section{Review of Literatures}

According to Marlina, et al. (2014) the success and failure experienced by students can be viewed as a learning experience. This learning experience will produce students' Self Efficacy in solving problems so that their learning abilities will increase, positive Self Efficacy is needed in learning so that students can achieve their learning objectives and achieve maximum learning achievement. One part of students' self-confidence is their selfbelief in mathematics or mathematical Self Efficacy. Therefore, a strong Self Efficacy is needed in students so that they can succeed in the mathematics learning process.

Self Efficacyhas an impact on motivation, so it is also related to student success. A student who has high Self Efficacy, if given learning they will enthusiastically / try hard to show his ability to achieve success. Conversely, if someone does not have high Self Efficacy, they tend to avoid assignments or carry them out half-heartedly so they will quickly give up if they encounter obstacles. 
Thus it can be said that Self Efficacy supports mathematical abilities. For this reason, it is necessary to design a learning that makes students 'Self Efficacy better in mathematics learning and also learning that improves students' mathematical representation abilities. So, several indicators of Self Efficacy can be formulated (Lestari and Yudhanegara, 2015) as follows:

1. Belief in one's own abilities.

2. Confidence in the ability to adapt and face difficult tasks.

3 . Belief in the ability to face challenges.

4. Confidence in the ability to complete specific tasks.

5. Confidence in the ability to complete several different tasks.

To achieve the above objectives, it is necessary to have a learning model that can overcome the educational problems that have been previously stated. Trianto (2009) states that the term learning model has a broader meaning compared to strategies, procedures and methods. According to Trianto (2009), the teaching model has characteristics, namely logical theoretical rationale prepared by its creators or developers, a basis for thinking about what and how students learn, teaching behavior required so that the model can be implemented successfully and the learning environment required. So that learning objectives can be achieved. The expected learning model is able to make students able to construct knowledge, can make students independent in learning, can increase student interaction, can train students to communicate ideas and can increase students' knowledge of solving problems. This is also stated by Rusman (2012) that: "The learning model can be used as a pattern of choice, meaning that teachers can choose an appropriate and efficient learning model to achieve their educational goals".

Problem-Based Learning which comes from English Problem-based Learning is a learning model that involves students to be active and collaborative. Khairani (2020) stated that PBL is a learning approach that begins with authentic and meaningful problems for students to find information on the solution and problem solving. This learning is learnercentered, who develops problem-solving abilities and independent learning abilities. Problem-based learning (PBL) is a learning concept that helps teachers create a learning environment that starts with important and relevant (related) problems for students, and allows students to gain a more realistic (real) learning experience. Problem Based Learning (PBL) is learning that focuses on solving problems by students themselves (Imelda, 2019).

Trianto (2009) defines "Problem-based learning model (Problem Based Learning) is a learning model that is based on many problems that require authentic investigation, namely investigations that require real solutions to real problems.

Meanwhile, Dewey (Trianto, 2009) also states that problem-based learning is an interaction between stimulus and response, which is the relationship between two directions of learning and the environment. The environment provides input to students in the form of help and problems, while the brain's nervous system functions to interpret the aid effectively so that the problems faced can be selected, assessed, and analyzed and sought solutions properly.

According to Arends (2008) Problem Based Learning has five characteristics, namely (1) Learning is based on problem solving. (2) There are interdisciplinary links. Although PBL is applied to certain subjects, for example chemistry, later solving the problem will involve other disciplines depending on the students' abilities and willingness. (3). Authentic investigation. PBL requires students to carry out authentic investigations to find concrete solutions to problems. (4) Producing products / works and presenting them. (5) Cooperation in working groups. 
In this study, problem-based learning is a learning model with reference to five main steps, namely: (1) providing orientation about the problem to students, (2) organizing students to learn, (3) guiding individual and group investigations, (4) developing and presenting the work, (5) analyzing and evaluating the problem-solving process.

Apart from the learning model, there are other things that can affect students' mathematical problem solving abilities and Self-Efficacy. This is because mathematics is a structured science and is related to each concept. This means that the mathematical knowledge that students have beforehand becomes the basis for understanding to learn the next material. Students with low or moderate KAM will be very different from students with high KAM in understanding the material given.

Furthermore, the problem found was the problem solving ability of students of SMP Negeri 1 Percut Sei Tuan, class VIII-4, which was still very low and students who had Self Efficacy were still low. In addition, the appropriate learning model to overcome these problems is to grow and develop high-order thinking in problem-oriented situations, including learning how to learn is a problem-based learning model. Based on this, the researcher was interested in researching "Improved Mathematical Problem Solving Ability and Self Efficacy for Class VIII Students of SMP Negeri 1 Percut Sei Tuan through Problem Based Learning Models".

\section{Research Methods}

This study took two parallel classes by applying different lessons, namely class VIII2 which is the experimental class and class VIII-3 which is the control class. The design used in this study was the non-equivalent control group design as shown in Table 1.

Table 1. Design of the Non-equivalent Control Group

\begin{tabular}{|l|c|c|c|}
\hline \multicolumn{1}{|c|}{ Class } & Pretest & Treatment & Postes \\
\hline Experiment & $\mathrm{O} 1$ & $\mathrm{X} 1$ & $\mathrm{O} 2$ \\
\hline Control & $\mathrm{O} 1$ & $\mathrm{X} 2$ & $\mathrm{O} 2$ \\
\hline
\end{tabular}

Information:

$\mathrm{X} 1=$ Problem Based Learning

X2 = Ordinary Learning

$0_{1} \quad=$ Pretest

$0_{2}=$ Postes

The population in this study were all students of SMP Negeri 1 Percut Sei Tuan, totaling 775 students, divided into 10 class VII study groups, 9 class VIII study groups, 9 class IX study groups. The instrument in the form of a test consisting of an initial mathematics ability test was used to groups of students into three groups, namely low, medium, and high student groups, mathematical problem solving abilities consisting of students 'pre-test and post-test, as well as a questionnaire to measure students' self-efficacy attitudes consisting of 30 statements with four answer choices, namely SS (Strongly Agree), S (Agree), TS (Disagree) and STS (Strongly Disagree). This study used the twoway Anava test. The following will describe the data analysis in this study which consists of homogeneity testing, normality testing, difference in average, the calculation of normalized gain, and hypothesis testing. After that, a two-way ANOVA test was carried out. All statistical calculations use the help of the SPSS 22 computer program. 


\section{Discussion}

The initial math ability test was given to classify students according to high, medium, and low KAM and also to check the equivalence of the two sample classes, namely the control class and the experimental class. The summary results of the calculation of students' initial mathematics ability (KAM) can be seen in table 2 below:

Table 2. Description of Initial Mathematical Ability Results

\begin{tabular}{|l|c|c|}
\hline \multicolumn{1}{|c|}{ Information } & $\begin{array}{c}\text { Control } \\
\text { Class }\end{array}$ & $\begin{array}{c}\text { Experiment } \\
\text { Class }\end{array}$ \\
\hline $\begin{array}{l}\text { The highest } \\
\text { score }\end{array}$ & 83 & 85 \\
\hline Lowest Value & 70 & 70 \\
\hline Average & 73.1 & 75 \\
\hline $\begin{array}{l}\text { Standard } \\
\text { Deviation }\end{array}$ & 9.34 & 8.1 \\
\hline
\end{tabular}

The mathematical problem solving ability test was conducted twice, namely before and after the implementation of learning activities after three meetings in each class. Giving posttest aims to determine the completeness of the mathematical problem-solving abilities obtained by students after being given learning treatment using problem-based learning models and ordinary learning models.

The description of the results of mathematical problem solving abilities using the usual learning model is shown in Table 3 below:

Table 3. Descriptions of Results of Mathematical Problem Solving Ability Using Ordinary Learning Models

\begin{tabular}{|l|c|c|}
\hline \multicolumn{1}{|c|}{ Information } & $\begin{array}{c}\text { Pretest Mathematical } \\
\text { Problem Solving Ability }\end{array}$ & $\begin{array}{c}\text { Postest Mathematical } \\
\text { Problem Solving Ability }\end{array}$ \\
\hline $\begin{array}{l}\text { The highest } \\
\text { score }\end{array}$ & 75 & 85 \\
\hline Lowest Value & 40 & 45 \\
\hline Average & 59.77 & 66.25 \\
\hline $\begin{array}{l}\text { Standard } \\
\text { Deviation }\end{array}$ & 11.15 & 11.08 \\
\hline
\end{tabular}

From Table 3, it shows that the average mathematical problem solving ability of students on the pretest results is 59.77 and the posttest results are 66.25.

The data obtained from the pretest and posttest results of students 'mathematical problem solving abilities in the ordinary learning model were analyzed to determine the increase in students' mathematical problem solving abilities. The increase is seen by calculating the $\mathrm{N}$ Gain value based on the results of the pretest and posttest in the Ordinary Learning Model. Based on the data obtained, a summary of the N-Gain results is based on the improvement categories that have been defined in the following table: 
Table 4. Summary of N-Gain Results on Ability Tests in Mathematical Problem Solving in Ordinary Learning Models

\begin{tabular}{|l|c|c|c|}
\hline \multicolumn{1}{|c|}{ Range } & $\begin{array}{c}\text { Category } \\
\text { Improvement }\end{array}$ & $\begin{array}{c}\text { The Number } \\
\text { of Students }\end{array}$ & Percentage \\
\hline $\mathrm{N} 0.7 \geq$ & High & 0 & $0 \%$ \\
\hline $0.3 \mathrm{~N} 0.7 \leq<$ & Moderate & 31 & $91.17 \%$ \\
\hline $\mathrm{N}<0.3$ & Low & 3 & $8.82 \%$ \\
\hline
\end{tabular}

Based on Table 4, it can be seen that there are no students who have increased their mathematical problem-solving abilities in the "High" category. There were 31 students (91.17\%) who experienced an increase in their mathematical problem-solving abilities $(91.17 \%)$, while 3 students $(8.82 \%)$ had an increase in their mathematical problem-solving abilities. These results indicate that all students have increased their mathematical problem solving abilities from the results of the pretest and posttest given. The N-Gain results of students when viewed based on the average value of the pretest and posttest mathematical problem solving abilities also increased. The mean pretest and posttest in the ordinary learning model were 59.77 and 66.25, respectively. Based on the results of the N-Gain calculation.

The description of the results of mathematical problem solving abilities using a problem-based learning model is shown in Table 5 below:

Table 5. Description of Results of Mathematical Problem Solving Ability Using ProblemBased Learning Models

\begin{tabular}{|l|c|c|}
\hline Information & $\begin{array}{c}\text { Pretest Mathematical } \\
\text { Problem Solving Ability }\end{array}$ & $\begin{array}{c}\text { Postest Mathematical } \\
\text { Problem Solving Ability }\end{array}$ \\
\hline $\begin{array}{l}\text { The highest } \\
\text { score }\end{array}$ & 75 & 95 \\
\hline Lowest Value & 37.5 & 57.5 \\
\hline Average & 66.25 & 76.17 \\
\hline $\begin{array}{l}\text { Standard } \\
\text { Deviation }\end{array}$ & 11.8 & 11.0 \\
\hline
\end{tabular}

From Table 5, it shows that the average mathematical problem solving ability of students on the pretest results is 66.25 and the posttest results are 76.17. The data obtained from the pretest and posttest results of students 'mathematical problem solving abilities using a problem-based learning model were analyzed to determine the increase in students' mathematical problem solving abilities. The increase is seen by calculating the $\mathrm{N}$-Gain value based on the results of the pretest and posttest students' mathematical problem solving abilities using a problem-based learning model

Based on the data obtained, a summary of the N-Gain results is based on the improvement categories that have been defined in Table 6 below.

Table 6. Summary of N-Gain Results on the Mathematical Problem Solving Ability Test Using a Problem Based Learning Model

\begin{tabular}{|l|c|c|c|}
\hline \multicolumn{1}{|c|}{ Range } & $\begin{array}{c}\text { Category } \\
\text { Improvement }\end{array}$ & $\begin{array}{c}\text { The number } \\
\text { of students }\end{array}$ & Percentage \\
\hline $\mathrm{N} 0.7 \geq$ & High & 5 & $14.70 \%$ \\
\hline $0.3 \mathrm{~N} 0.7 \leq<$ & Moderate & 22 & $64.70 \%$ \\
\hline $\mathrm{N}<0.3$ & Low & 7 & $20.58 \%$ \\
\hline
\end{tabular}


Based on Table 6, it can be seen that there are 5 students $(14.70 \%)$ who have increased their mathematical problem-solving abilities in the "High" category. There were 22 students $(64.70 \%)$ who experienced an increase in their mathematical problem-solving abilities (64.70\%), while 7 students $(20.58 \%)$ had an increase in their mathematical problem-solving abilities. These results indicate that all students have increased their mathematical problem-solving abilities from the results of the pretest and posttest given.

The N-Gain results of students when viewed based on the average value of the pretest and posttest mathematical problem solving abilities also increased. The mean pretest and posttest in Using the Learning Model were 63.60 and 80.09 respectively, which resulted in the difference between the pretest and posttest scores of 16.48. Based on the results of the N-Gain calculation, it was found that the increase in students' mathematical problem-solving abilities used a problem-based learning model valued at 0.45 or in the "Medium" category. Thus the use of problem-based learning models can improve students' mathematical problem solving abilities.

Student mathematical Self Efficacy questionnaire data were collected and analyzed to determine the students' mathematical Self Efficacy ability before the learning treatment. The answer choices from the Self Efficacy questionnaire items use the Linkert scale. The type of data obtained from the answers to the questionnaire is an ordinal scale.

Descriptively it can be concluded that the mathematical Self Efficacy of students using the ordinary learning model that has been developed based on the KAM category (high, medium and low) results in students who have Self Efficacy in the high group there are 4 people, in the moderate group there are 24 students and in the group low there are 6 students. The results of the mathematical Self Efficacy questionnaire for each indicator are shown in Table 7 as follows.

Table 7. Results of the Mathematical Self Efficacy Questionnaire for Each Indicator Using the Ordinary Learning Model

\begin{tabular}{|l|l|l|}
\hline No. & \multicolumn{1}{|c|}{ Self Efficacy Indicator } & Score \\
\hline 1. & Task Difficulty Level (Level) & 3.27 \\
\hline 2. & Degree of stability, belief or hope (strength) & 3.18 \\
\hline 3. & Broad field of behavior (generality) & 3.22 \\
\hline
\end{tabular}

From the table above it can be seen that the average score on the indicator of the difficulty level of the task (Level) is 3.27; the average value on the indicator of the degree of stability, confidence or hope (strength) was 3.18; and the average value on the indicator of the difficulty level of the task (level) is 3.22.

In a class with a problem-based learning model, the student's mathematical Self Efficacy scale was also given the same as the control class, the Self Efficacy scale in the experimental class was also given after the students had finished working on the mathematical problem-solving ability test. This Self Efficacy scale is still the same as the Self Efficacy scale given to the control class which consists of 30 statement items, each statement item is prepared according to the Self Efficacy indicator that the researcher has set in Chapter III. Each Self Efficacy indicator contains statements that are randomly distributed on the Self Efficacy scale.

Descriptively it can be concluded that students' mathematical Self Efficacy after using problem-based learning tools that have been developed based on the KAM category (high, medium and low) results in students who have Self Efficacy in the high group there are 7 people, in the moderate group there are 23 students and at low group there are 4 
students. The results of the mathematical Self Efficacy questionnaire for each indicator are shown in Table 8 as follows:

Table 8. Results of the Mathematical Self Efficacy Questionnaire for Each Indicator in Trial II

\begin{tabular}{|l|l|l|}
\hline No. & \multicolumn{1}{|c|}{ Self Efficacy Indicator } & Score \\
\hline 1. & Task Difficulty Level (Level) & 3.39 \\
\hline 2. & Degree of stability, belief or hope (strength) & 3.28 \\
\hline 3. & Broad field of behavior (generality) & 3.29 \\
\hline
\end{tabular}

From Table 8 it can be seen that the average value on the indicator of the level of difficulty of the task (Level) is 3.39, the average value on the indicator of the degree of stability, confidence or expectation (strength) is 3.29 and the average value on the indicator area the field of behavior (generality), which is 3.29.

Testing the first hypothesis, namely the results of students' mathematical problemsolving abilities in the problem-based learning model class were higher than in the ordinary learning model class.

Table 9. Analys is Results for Improved Mathematical Problem Solving Ability

\begin{tabular}{|l|l|l|l|l|l|}
\hline \multicolumn{5}{|l|}{ Tests of Between-Subjects Effects } \\
\hline Dependent Variable: test & \multicolumn{1}{|c|}{$\begin{array}{c}\text { Type III Sum of } \\
\text { Squares }\end{array}$} & df & $\begin{array}{c}\text { Mean } \\
\text { Square }\end{array}$ & \multicolumn{1}{|c|}{ F } & Sig. \\
\hline Corrected Model & $8534.482 \mathrm{a}$ & 5 & 1706,896 & 73,790 & .000 \\
\hline Intercept & 291690,674 & 1 & 291690,674 & 12609,904 & .000 \\
\hline KAM & 6846,557 & 2 & 3423,279 & 147,990 & .000 \\
\hline Class & 1460,687 & 1 & 1460,687 & 63,146 & .000 \\
\hline Error & 1434,176 & 62 & 23,132 & & \\
\hline Total & 354818,750 & 68 & & & \\
\hline Corrected Total & 9968,658 & 67 & & & \\
\hline a. R Squared $=.856$ (Adjusted R Squared $=.845)$ & & \\
\hline
\end{tabular}

Based on the ANOVA $2 \times 2$ calculation, it is obtained Fcount $=88.82$ while the Ftable value $=2.36$ for $\mathrm{dk}(1.62)$ and a significant level of $5 \%$. It turns out that the value of Fcount> Ftable, so that $\mathrm{Ho}$ is rejected and $\mathrm{Ha}$ is accepted. Then from table 4. The probability value (sig) is smaller than 0.05 so that $\mathrm{H} 0$ is rejected. Thus it can be concluded that the results of the mathematics problem solving abilities of students who are taught with problem-based learning models are better than those taught with ordinary learning models. This can also be seen from the average results of students' mathematical problemsolving abilities taught with problem-based learning models (76.17) higher than those taught with ordinary learning models $(66.25), \bar{X}=\bar{X}=$

The second test is that the results of the student's Self Efficacy questionnaire in the problem-based learning model class are higher than in the ordinary learning model class.

Table 10. Analysis Results for Improving Mathematical Self Efficacy

\begin{tabular}{|l|l|l|l|c|r|}
\hline \multicolumn{5}{|l|}{ Tests of Between-Subjects Effects } \\
\hline Dependent Variable: test \\
\hline \multicolumn{1}{|c|}{ Source } & Type III Sum of Squares & df & Mean Square & F & Sig. \\
\hline Corrected Model & $5025.152 \mathrm{a}$ & 5 & 1005,030 & 52,536 & .000 \\
\hline Intercept & 557335,379 & 1 & 557335,379 & 29133,533 & .000 \\
\hline
\end{tabular}




\begin{tabular}{|l|l|l|l|l|l|}
\hline KAM & 4857,035 & 2 & 2428,517 & 126,946 & .000 \\
\hline class & 136,551 & 1 & 136,551 & 7,138 & 010 \\
\hline Error & 1186,083 & 62 & 19,130 & & \\
\hline Total & 662816,000 & 68 & & & \\
\hline Corrected Total & 6211,235 & 67 & & & \\
\hline \multicolumn{2}{|l|}{ a. R Squared $=.809$ (Adjusted R Squared $=.794)$} & & & \\
\hline
\end{tabular}

Based on the ANOVA $2 \times 2$ calculation, it is obtained Fcount $=81.75$ while Ftable value $=2.36$ for $\mathrm{dk}(1.62)$ and a significant level of $5 \%$. It turns out that the value of Fcount> Ftable, so that $\mathrm{Ho}$ is rejected and $\mathrm{Ha}$ is accepted. Then from table 4. The probability value (sig) is smaller than 0.05 so that $\mathrm{H} 0$ is rejected. Thus it can be concluded that the results of students' Self Efficacy in the problem-based learning model class are higher than in the ordinary learning model class. This can also be seen from the average results of the mathematics Self Efficacy questionnaire of students with the experimental class (99.7) which are higher than the average results of the mathematics Self Efficacy questionnaire of students with the control class (96.8). $\bar{X}=\bar{X}=$

The third test is that there is an interaction between learning and initial ability to improve mathematical problem solving abilities.

Table 11. Analys is Results for the Interaction Between Learning and Early Ability on Mathematical Problem Solving Ability

\begin{tabular}{|l|l|l|l|l|l|}
\hline \multicolumn{6}{|l|}{ Tests of Betwe en-Subjects Effects } \\
\hline Dependent Variable: test \\
\hline \multicolumn{1}{|c|}{ Source } & \multicolumn{1}{|c|}{$\begin{array}{c}\text { Type III Sum of } \\
\text { Squares }\end{array}$} & df & Mean Square & F & Sig. \\
\hline Corrected Model & $8534.482 \mathrm{a}$ & 5 & 1706,896 & 73,790 & .000 \\
\hline Intercept & 291690,674 & 1 & 291690,674 & 12609,904 & .000 \\
\hline KAM & 6846,557 & 2 & 3423,279 & 147,990 & .000 \\
\hline Class & 1460,687 & 1 & 1460,687 & 63,146 & .000 \\
\hline KAM * class & 2,724 & 2 & 1,362 & .059 & .943 \\
\hline Error & 1434,176 & 62 & 23,132 & & \\
\hline Total & 354818,750 & 68 & & & \\
\hline Corrected Total & 9968,658 & 67 & & & \\
\hline a. R Squared $=.856$ (Adjusted R Squared $=.845)$ & & & \\
\hline
\end{tabular}

Based on the calculation of $2 \times 2$ factorial anova obtained Fcount $=0.667$ while the Ftable value $=2.63$ for $\mathrm{dk}(1.62)$ and a significant level of $5 \%$. It turns out that the value of Fcount <Ftable, so that Ho is accepted. Then from table 4. The probability value (sig) is smaller than 0.05 so that $\mathrm{H} 0$ is rejected. Thus it can be concluded that there is no interaction between learning and initial ability to increase mathematical problem solving abilities. For more details, it can be seen in the following figure: 


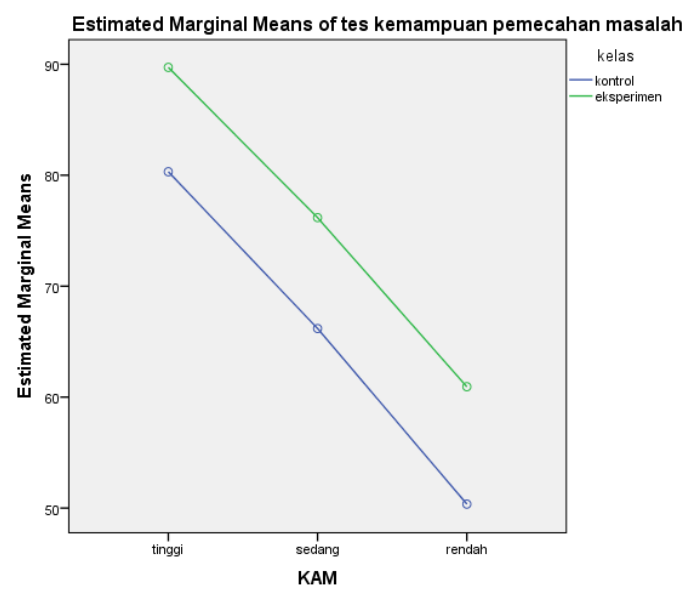

Figure 1. The Interaction Between Learning and Early Skills on Mathematical Problem Solving Ability

Based on the figure, it can be seen that the control class line does not intersect with the experimental class line. Based on the difference in the average increase in problemsolving abilities, it is found that learning with the ordinary model and the problem-based approach model is not influenced by student KAM. This means that there is no joint influence that the student learning model and KAM contribute to students' mathematical problem solving abilities. So it can be concluded that there is no interaction between the learning model and students 'KAM on students' problem solving abilities.

The third test is that there is an interaction between learning and initial ability to increase students' Self Efficacy.

Table 12. Analys is Results for the Interaction Between Learning and Early Ability on Mathematical Self Efficacy

\begin{tabular}{|l|l|l|l|l|l|}
\hline \multicolumn{6}{|l|}{ Tests of Between-Subjects Effects } \\
\hline \multicolumn{1}{|c|}{ Source } & \multicolumn{1}{|c|}{$\begin{array}{c}\text { Type III Sum of } \\
\text { Squares }\end{array}$} & df & Mean Square & \multicolumn{1}{|c|}{ F } & Sig. \\
\hline Corrected Model & $5025.152 \mathrm{a}$ & 5 & 1005,030 & 52,536 & .000 \\
\hline Intercept & 557335,379 & 1 & 557335,379 & $\begin{array}{l}29133,53 \\
3\end{array}$ & .000 \\
\hline KAM & 4857,035 & 2 & 2428,517 & 126,946 & .000 \\
\hline Class & 136,551 & 1 & 136,551 & 7,138 & .010 \\
\hline KAM * class & 1,582 & 2 & .791 & .041 & .960 \\
\hline Error & 1186,083 & 62 & 19,130 & & \\
\hline Total & 662816,000 & 68 & & & \\
\hline Corrected Total & 6211,235 & 67 & & & \\
\hline a. R Squared $=.809$ (Adjusted R Squared $=.794)$ & & \\
\hline
\end{tabular}

Based on the calculation of $2 \times 2$ factorial anova obtained Fcount $=1.1$, while the value of Ftable $=2.63$ for $\mathrm{dk}(1.62)$ and a significant level of $5 \%$. It turns out that the value of Fcount <Ftable, so that Ho is accepted. Thus it can be concluded that there is no interaction between learning and initial ability to increase mathematical Self Efficacy. For more details, it can be seen in Figure 2 below: 


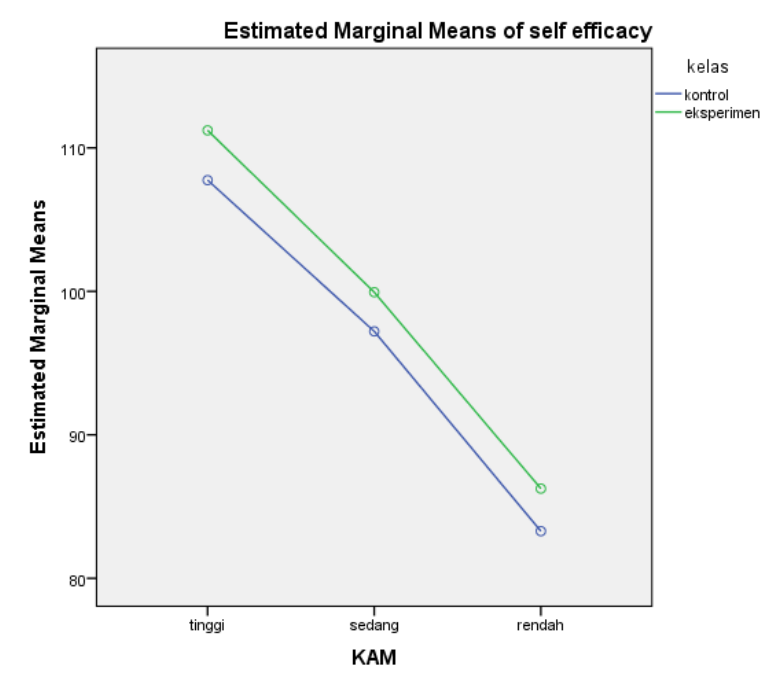

Figure 2. The Interaction Between Learning and Early Ability on Mathematical Self Efficacy

Based on the figure, it can be seen that the control class line does not intersect with the experimental class line. Based on the difference in the mean Self Efficacy, it is found that learning with the ordinary model and the problem-based approach model is not influenced by student KAM. This means that there is no joint influence that is contributed by the learning model and students 'KAM on students' mathematical Self Efficacy. So it can be concluded that there is no interaction between the learning model and students 'KAM on students' Self Efficacy.

\subsection{Results of Students' Mathematical Solving Ability Tests with Ordinary and Problem-Based Learning Models}

Mathematical problem solving skills help students to solve mathematical problems so that problem solving goes well as expected. The low ability of students to solve mathematical problems can be caused by the learning activities implemented in the classroom. In general, mathematics learning is carried out using the lecture method and assignments in the form of routine questions. Routine questions given by the teacher may not necessarily improve students' mathematical problem solving abilities. Mathematics learning that is carried out in schools should be arranged in order to improve students' mathematical problem solving abilities.

Based on the results of statistical analysis with two-way ANOVA, it shows that the results of the first hypothesis test are obtained Fcount> Ftable, namely 81.75> 2.63 and the results of SPSS-22 for the learning model are $0.00<0.05$, so Ho is rejected and $\mathrm{Ha}$ is accepted. The conclusion is that there is a difference in the improvement between student learning outcomes in the ordinary learning model class and student learning outcomes in the problem-based learning model class.

The results of this study are in line with research relevant to problem-based learning models, namely the results of research by Delina et al. (2015) show that the increase in students' mathematical problem-solving abilities through problem-based learning models is higher than the increase in mathematical problem solving abilities of students who obtain conventional learning models. that's from Junita Amalia, Hendra Syarifuddin, and Nilawasti ZA (2014) which show that problem-based learning can be used as an alternative in improving students' problem-solving abilities. In addition, Desi Indarwati, 


\subsection{Self Efficacy Questionnaire Results with Ordinary and Problem-Based Learning Models}

Self Efficacyis an individual's belief or belief regarding his / her ability to organize, perform a task, achieve a goal, produce something and implement actions to display certain skills. Self Efficacy comes from experiences of success, experiences of other individuals, verbal persuasion, and individual physiological states.

Based on the results of statistical analysis with two-way ANOVA, it shows that the results of the second hypothesis test are obtained Fcount> Ftable, namely 7.16>2.63 and the results of SPSS-22 for the learning model are $0.00<0.05$, so Ho is rejected and Ha is accepted. The conclusion is that there is a difference in the improvement between the learning models against Self Efficacy.

The results of this study are in line with the Research Results. Wiratmaja et al. (2014) found that (1) there is a significant difference between learning models on selfefficacy and emotional intelligence $(\mathrm{F}=38,243 ; \mathrm{p}<0.05)$, (2) there are There is a significant difference in self-efficacy between groups of students who take problem-based learning and direct learning $(F=73.846 ; p<0.05)$, and (3) there are significant differences in emotional intelligence between groups of students who take problem-based learning and direct learning (3). $\mathrm{F}=11.249 ; \mathrm{p}<0.05$ ).

Based on these studies, it is found that problem-based learning models provide better results in the learning process. Thus, the learning process that uses problem-based learning can improve students' mathematical problem solving skills and Self Efficacy.

\subsection{The Interaction Between Learning Models and Initial Ability Towards Increased Mathematical Problem Solving Ability}

Interaction is defined as the difference between each factor tested in a quantitative study. The factors in this study are the learning model and students' initial abilities. This learning model consists of ordinary learning models and problem-based learning models. For KAM students consist of high, medium, and low. The findings of this study indicate that there is significantly no interaction between the learning model and students' KAM on their mathematical problem solving abilities

Based on the results of statistical analysis with two-way ANOVA, it shows that the results of the third hypothesis test are obtained $\chi_{\text {count }}^{2}<\chi^{2}$ table namely $0.667<2.63$ and the results of SPSS-22 for the learning model obtained 0.943>0.05, so Hodaccepted and Haditolak. Then from table 4 . The probability value (sig) is smaller than 0.05 so that H0 is rejected. Thus it can be concluded that there is no interaction between learning and initial ability to increase mathematical problem solving abilities. This indicates that the learning model and KAM simultaneously do not affect students' mathematical problem solving abilities.

Theoretically, the interaction is caused by the learning used during the teaching and learning process which is able to develop students' abilities in mathematics not because of the different initial abilities of students.

\subsection{The Interaction Between Learning Models and Early Ability Against Mathematical Self Efficacy}

Interaction is defined as the difference between each factor tested in a quantitative study. As for the factors in this study are the learning model and students' initial abilities. This learning model consists of ordinary learning models and problem-based learning models. For KAM students consist of high, medium, and low. The findings of this study 
indicate that there is significantly no interaction between the learning model and students' KAM on Self Effiacy.

Based on the results of statistical analysis with two-way ANOVA, it shows that the

results of the third hypothesis test are obtained $\chi_{\text {count }}^{2}<\chi^{2}$ table namely $1.1<2.63$ and the results of SPSS- 22 for the learning model obtained $0.940<0.05$, so Ho was accepted and Haditolak. Then from table 4 . The probability value (sig) is smaller than 0.05 so that $\mathrm{H} 0$ is rejected. Thus it can be concluded that there is no interaction between learning and initial ability to increase mathematical problem solving abilities. This shows that the learning model and KAM simultaneously do not affect students' mathematical Self Efficacy.

\section{Conclusion}

Based on the results of data analysis and discussion in this study, the following conclusions are stated:

1. There was an increase in the results of problem-solving abilities, namely the results of students' mathematical problem-solving abilities taught by problem-based learning models were better than those taught with ordinary learning models.

2. There was an increase in the results of Self Efficacy, namely the results of the Mathematical Self Efficacy of students who were taught with problem-based learning models were better than those taught with ordinary learning models.

3. There is no interaction between learning and initial ability to increase mathematical problem solving abilities.

4. There is no interaction between learning and initial ability to increase mathematical Self Efficacy

\section{References}

Arends, R. 2008. Learning to Teach. Penerjemah: Helly Prajitno \& Sr Mulyani. New York: McGraw Hill Company.

Banjarnahor. 2018. Analisis kemampuan berpikir intuisi mahasiswa prodi pendidikan matematika berbasis pendekatan matematika realistik. Prosiding SiManTap 2018: Volume 2, halaman 199-204.

Delina, Sri, dkk. 2015. Peningkatan Kemampuan Pemecahan Masalah Matematik dan Kemandirian Belajar Siswa SMP Melalui Model Pembelajaran Berbasis Masalah. Jurnal Paradikma, Volume 8, No. 3.

Fitri, S., \& Zahari, C.L. (2019). The implementation of blended learning to improve understanding of mathematics. The Sixth Seminar Nasional Pendidikan Matematika Universitas Ahmad Dahlan 2018: IOP Conf. Series: Journal of Physics: Conf. Series 1188 (2019) 012109, 2018, doi:10.1088/1742-6596/1188/1/012109.

Fitri, S., Syahputra, E., \& Syahputra, H. (2019). Blended Learning Rotation Model of Cognitive Conflict Strategy to Improve Mathematical Resilience in High School Students. International Journal of Scientific \& Technology Research, 1 (1).

Imelda, Anzelina, D. (2019). Students' Activities in Learning with Problem Based Learning Based Module to Enhance Students' HOTS on the Subject of Straight Line Equations. Budapest International Research and Critics in Linguistics and Education (BirLE) Journal Vol 2 (4): 552-559. 
Indarwati, Desi., Wahyudi., \& Ratu, Novisita. (2014). Peningkatan kemampuan pemecahan masalah matematika melalui penerapan problem based learning untuk siswa kelas V SD.Jurnal Satya Widya. 30(1): halaman 17-27.

Junita, Amalia., Hendra Syarifuddin, Dan Nilawasti Za.(2014). Pengaruh Penerapan Pembelajaran Berbasis Masalah terhadap Kemampuan Pemecahan Masalah Siswa Kelas VIII SMPN 8 Padang. Jurnal Pendidikan Matematika : Vol. 3 No. 2 , Part 1 : Hal. 38-43.

Khairani, S., Suyanti, R.D., Saragi, D. (2020). The Influence of Problem Based Learning (PBL) Model Collaborative and Learning Motivation Based on Students' Critical Thinking Ability Science Subjects in Class V State Elementary School 105390 Island Image. Budapest International Research and Critics in Linguistics and Education (BirLE) Journal Vol 3 (3): 1581-1590.

Kirkley. 2003. Principles for Teaching Problem Solving. Indiana: Plato Learning.

Lestari dan Yudhanegara. 2015. Penelitian Pendidikan Matematika. Bandung : PT. Refika Aditama.

Marlina, dkk. 2014. Peningkatan Kemampuan Komunikasi dan Self-Efficacy Siswa SMP dengan Menggunakan Pendekatan Diskursif. Jurnal Didaktik Matematika, Vol. 1, No. 1.

Rusman. 2012. Model-model Pembelajaran. Jakarta: PT. RajaGrafindo Persada.

Trianto. 2009. Mendesain Model Pembelajaran Inovatif-Progresif: Konsep, Landasan, dan Implementasinya pada Kurikulum Tingkat Satuan Pendidikan (KTSP). Jakarta: Kencana. 